\title{
Effectiveness of Classical Music and Qur'an Murottal Therapies on Patients With Hypertension in Middle Adulthood for Work Area of Sibela Surakarta Health Center
}

\author{
$1^{\text {st }} \mathrm{W}$ Wahyuni \\ Nursing bachelor Program \\ Aisyiyah Surakarta School of Health \\ Science \\ Surakarta, Indonesia \\ yunyskh@gmail.com \\ $4^{\text {th }}$ I Indarwati \\ Nursing bachelor Program \\ Aisyiyah Surakarta School of Health \\ Science \\ Surakarta, Indonesia
}

\begin{abstract}
Hypertension is categorized as the silent disease since the patients do not know that they have it before taking the blood pressure check-up. Hypertension which is not treated properly and prolonged can effect to stroke, heart attack, and main factor of chronicle kidney failure. The hypertension can non-pharmacology. The classical music and Qur'an Murottal therapies. to identify the effectiveness of classical music and Qur'an murottal on patients with hypertension in middle adulthood. the type of research is quasi experimental design with the method of two groups in pre and post test design. The sample of this research is 32 persons result shows the systolic score of $p$ value is $0,005(p<0,05)$, it means there is the meaningful difference, while the diastolic score of $p$ value shows 0,287 $(p>0,05)$, it means there is no meaningful difference. The drop mean of blood pressure in classical music therapy group is systolic $\mathrm{s4,06} \mathrm{mmHg}$ and diastolic $2,54 \mathrm{mmHg}$, while the Qur'an murottal therapy group is systolic $6,90 \mathrm{mmHg}$ and 3,27 mmHg.: this research proves that the Qur'an murottal therapy is more effective in dropping the blood pressure than the classical music therapy.
\end{abstract}

Keywords-Classical Music, Qur'an Murottal Therapies, Hypertension

\section{INTRODUCTION}

Hypertension is one of main causes upon $45 \%$ death of heart attack and $51 \%$ death of stroke [1]. In general, it indicates a condition of someone who gets the surge of up normal blood pressure which described by the systolic and diastolic scores when checking up. The gap line of blood pressure for adult up to 18 years old that considered normally is less than $130 / 85 \mathrm{mmHg}$. Otherwise, it is called as hypertension, if value of blood pressure shows more than $140 / 90 \mathrm{~mm}$ Hgs. When this disease is not treated properly and prolonged, it is potentially impacted to stroke, heart attack, and being main factor of chronicle kidney failure [2].

According to WHO data in 2015, 22,1\% from the number of world population aged more than 18 years old or 1.13 billion people in the world are the hypertension patients. Then, based on the result of basic medical study (RISKESDAS) about the prevalence of hypertension patients, the diagnosis by doctors, and the blood pressure check-up for people who aged more than 18 years old is about $25,8 \%$ of the total population aged more than 18 years old in 2013 .

The aim of the hypertension therapy is to achieve and maintain the systolic blood pressure under $140 \mathrm{mmHg}$, the diastolic blood pressure under $90 \mathrm{mmHg}$ and control the risk factors of hypertension. Its therapy can be conducted through pharmacology approach or utilizing medicine and non-pharmacology approach or modifying life style [3]. Non pharmacology therapy concerns on decreasing stress, controlling weight by exercising sport, applying low cholesterol diet, and reducing salt consumption [4].

Progressive Muscle Relaxation and SIRMA Dyeing Tea therapy has the significant influence toward the hypertension level on elderly, so this therapy can be recommended as one of the hypertension complementary therapies [5]

The relaxation therapy can decrease the blood pressure, this case has been proven in the previous studies [6].

There is an effect of giving tomato juice to reduce blood pressure in patients primary hypertension stage 1 (W Wahyuni and Suryani 2017)

One kind of relaxation therapy is listening music. Classical music is often considered as the recommendation for music therapy, Mozart's music, for instance. The characteristics of Mozart's music are high frequency tones, wide range of tones, and dynamic tempo. [4]. The music therapy has the stimulant to increase the release of endorphin and to distract from pain. This therapy also gives the relax feeling of mind or on the body from its listener, the relax feeling can influence the heart beat and blood pressure according to the frequency, temp and music volume that have heard [8]. In addition, listening music can activate the limbic system to bring 
relax feeling. This condition impacts the decreasing of blood pressure. Then, music is able to stimulate the body for producing the nitric oxide (NO) molecules. These molecules work on blood vessel tonus so it can drop the blood pressure (Kurniadi and Ulfah 2014).

Murottal is a recording compilation of reading Qur'an verses which emphasizes on vocal cords with paying close to tajweed in producing its letters and waqf. In addition, murottal Qur'an has the human's voice elements which able to decrease stress hormone, secreting natural endorphin hormone, giving relax feeling, reducing fear, anxiety, and tension. Listening Qur'an murottal can help neuropeptidae secretion in giving comfort and enjoyment for the listeners (Yuniarsih, 2017). Based on the study conducted by Wirakhmi (2016), murottal used is Ar-Rahman that presented by Ahmad Saud and it has been validated in laboratory at Art and Culture Faculty of Semarang University. Surah Ar-Rahman has the medium timbre, pitch on $44 \mathrm{~Hz}$, regular and consistent harmony, rythmandate, volume on 60 decibels, medium amplitude intensity. This surah has the short verses which possibly to create the relaxation effect for listeners when hearing it.

\section{METHOD}

The type research was quasi experimental design with the method of two groups in pre and post test design. The sample of it was 32 persons who consisted of hypertension patients in work area of Sibela Health Care.

The method of collecting sample used was purposive sampling. The test that used to identify the difference among both of classical music and Qur'an murottal groups were using Independent t test.

\section{RESULT}

\section{A. Univariat analysis}

Based on the analysis of the classical music group that consisted of 16 respondents before conducted the treatment, the mean score of systolic blood pressure was 147,60 , while the mean of diastolic blood pressure was 93,27. These results could be categorized into mild hypertension. In detail, from the total of 16 respondents, it showed that 10 respondents or $62,5 \%$ were in mild hypertension, while 6 respondents or $37 \%$ were in medium hypertension.

After the patients were treated through classical music therapy, the mean score of their systolic blood pressure was $143,54 \mathrm{mmHg}$ and its mean score of diastolic blood pressure was $90,73 \mathrm{mmHg}$. These scores were categorized into mild hypertension with the data including 5 respondents were in pre-hypertension, 8 respondents were in mild hypertension, and 3 respondents were in medium hypertension.

Based on the analysis of the Qur'an murottal group which consisted of 16 respondents before conducted the treatment, the mean score of systolic blood pressure was 150,06 , while the mean score of diastolic blood pressure was 93,18, so it was categorized into medium hypertension. From 16 respondents of Qur'an murottal group, it could be seen that 9 respondents were in mild hypertension and 7 respondents were in medium hypertension. After giving the treatment of Qur'an murottal therapy, the mean score of systolic blood pressure was $143,17 \mathrm{mmHg}$ and the mean score of diastolic blood pressure was $89,91 \mathrm{mmHg}$. These score of blood pressure could be categorized into mild hypertension. For Qur'an murottal group, 6 respondents were in pre-hypertension, 6 respondents were in mild hypertension, and 4 respondents were in medium hypertension.

\section{B. Bivariat Analysis}

TABLE 1 THE COMPARATION OF SYSTOLIC AND DIASTOLIC BLOOD PRESSURE IN PRE AND POST TREATMENT BY CLASSICAL MUSIC THERAPY

\begin{tabular}{lcccc}
\hline $\begin{array}{l}\text { Blood } \\
\text { Pressure }\end{array}$ & Pretest & Posttest & $p$ value & Difference \\
\hline $\begin{array}{l}\text { Systolic } \\
\text { (mean) }\end{array}$ & 147,60 & 143,54 &, $001^{\mathrm{a}}$ & 4,06 \\
$\begin{array}{l}\text { Diastolic } \\
\text { (mean) }\end{array}$ & 93,27 & 90,73 &, $011^{\mathrm{a}}$ & 2,54 \\
\hline
\end{tabular}

Detail: a; Wilcoxon Test (Paired Group; Abnormal) Source: Primary Data in 2018

On the classical music group, it could be seen that score of $p$ value in systolic blood pressure was $0,001(\mathrm{p}<0,05)$, while $p$ value of diastolic blood pressure was 0,011 $(\mathrm{p}<0,05)$. By these result, it showed there was a significant difference on classical music group.

The drop score of systolic blood pressure was 4,06 $\mathrm{mmHg}$ and its diastolic blood pressure was $2,54 \mathrm{mmHg}$. This result is accordance with the study conducted by Mahatidanar and Nisa (2017) which showed the drop of blood pressure on hypertension patients with mean score before therapy was $149 / 90,8 \mathrm{mmHg}$, while the mean score after therapy was $145,2 / 86,4 \mathrm{mmHg}$.

TABLE2 THE COMPARATION OF SYSTOLIC AND DIASTOLIC BLOOD PRESSURE IN PRE AND POST TREATMENT BY QURAN MUROTAL THERAPY

\begin{tabular}{|l|c|c|c|c|}
\hline Blood Pressure & Pretest & Posttest & $p$ value & Difference \\
\hline $\begin{array}{l}\text { Systolic } \\
\text { (mean) }\end{array}$ & 150,06 & 143,17 & $0,000^{\mathrm{a}}$ & 6,90 \\
\hline $\begin{array}{l}\text { Diastolic } \\
\text { (mean) }\end{array}$ & 93,18 & 89,91 & $0,001^{\mathrm{a}}$ & 3,27 \\
\hline
\end{tabular}

Detail: a; Wilcoxon Test (Paired Group; abnormal)

Source : Primay Data in 2018

On the Qur'an murottal group, the score of $p$ value of systolic blood pressure was $0,000(p<0,05)$, while the value of diastolic blood pressure was $0,001 \quad(p<0,05)$. Based on the result, it could be concluded that there was a significant different on the Qur'an murottal group. Then, the drop score of systolic blood pressure was $6,90 \mathrm{mmHg}$ and its diastolic blood pressure was $3,27 \mathrm{mmHg}$. This result is in line with the study conducted by Erlina and Raharjo (2016) which showed that Qur'an murottal therapy using Ar-Rahmah could drop the blood pressure for hypertension patients of RSUDZA Banda Aceh. 
TABLE 3. THE DROP DIFFERENCE OF BLOOD PRESSURE AMONG THE CLASSICAL MUSIC AND QUR'AN MUROTTAL GROUPS

\begin{tabular}{|l|c|c|c|}
\hline & $\begin{array}{c}\text { Classical } \\
\text { Music }\end{array}$ & $\begin{array}{c}\text { Qur'an } \\
\text { Murottal }\end{array}$ & $p$ \\
\hline $\begin{array}{l}\text { Mean of Systolic } \\
\text { Difference }\end{array}$ & 4,06 & 6,90 & $0,003^{\mathrm{a}}$ \\
\hline $\begin{array}{l}\text { Mean of Diastolic } \\
\text { Difference }\end{array}$ & 2,54 & 3,27 & $0,287^{\mathrm{b}}$ \\
\hline
\end{tabular}

\section{Detail: a; Independent t test (Paired Group; Normal) b; Mann-Whitney (Paired Group; abnormal) \\ Source : Primay Data in 2018}

On the test of different influence between the classical music and the Qur'an murottal groups, it could be concluded the score of $p$ value was $0,003(p<0,05)$, while the score of $p$ value was $0.278(\mathrm{p}>0,05)$ on the drop score of diastolic blood pressure. It could be meant that there was significant difference on the drop of blood pressure among the classical music and the Qur'an murottal groups for the systolic blood pressure, while the diastolic blood pressure did not show the meaningful difference.

Furthermore, the Qur'an murottal group showed more in drop of blood pressure than the classical music group. It could be proved on the difference score of blood pressure in pre and post using Qur'an murottal therapy was $6,90 \mathrm{mmHg}$, while the classical music therapy just dropped 4,06 mmHg. Thus, the Qur'an murottal therapy was more effective to drop the blood pressure than classical music therapy. For the mean of difference in pre and post therapy, Qur'an murottal therapy showed $6,90 / 3,27 \mathrm{mmHg}$, while the classical music therapy was $4,06 / 2,54 \mathrm{mmHg}$.

Listening to murotal surah Ar Rahman is more effective in reducing pain due to hypertension compared with listening to music mozart. Listening to murotal surah Ar Rahman can be recommended as a complementary therapy option and non pharmacology in reducing pain of patients with hypertension.[10]

This current research is in line with the study conducted by Haryanto, et al (2014), which compared the difference of classical music therapy against the Qur'an murottal therapy on elderly hypertension patients in House of Tresna Wherdha Mulya Darma Pontianak. Shortly, those study showed that there was difference among classical music therapy and Qur'an murottal therapy in dropping blood pressure. It is proved that the Qur'an murottal therapy is more effective than classical music therapy.

Preferred music with lyrics increases the heart rate but no change in either systolic or diastolic blood pressure was seen. Though the reaction time before error correction in stroop card was not significant, errors were significantly less as well as reaction time after error addition was also less. It suggests preferred music can increase heart rate and also improves the selective attention.[12]

Thus, the researcher can assume that the drop of blood pressure is more effective by applying Qur'an murottal therapy. For this case, the respondents that taken by researcher are moslem patients so that when hearing Qur'an murottal, they are more appreciate as worth in their belief.

\section{CONCLUSION}

Based on the research about the effectiveness of classical music and Qur'an murottal therapies on the patients with hypertension in middle adulthood for work area of Sibela Surakarta Health Center, it can be concluded that the difference of drop on blood pressure among classical music and Qur'an murottal groups is pointed out by the score of drop on the systolic blood pressure, while the drop on the diastolic blood pressure does not show the meaningful difference among these groups. Qur'an murottal therapy is more effective in dropping the blood pressure on the patients with hypertension in work area of Sibela Surakarta Health Center than classical music therapy.

\section{REFERENCES}

[1] World Health Organization, "A Global brief oh hypertension," p 9, 2013.

[2] Herlambang, Menaklukkan Hipertensi dan Diabetes : Mendeteksi Mencegah Dan Mengobati Dengan Cara Medis Dan Herbal. Jakarta: Tugu Publisher, 2013.

[3] A. Sofro, M. A. U., dan Dito, 5 Menit Memahami 55 Problematika Kesehatan. Jogjakarta: D-Medika, 2013.

[4] N. Kurniadi, H., dan Ulfah, Stop! Diabetes Hipertensi Kolesterol Tinggi Jantung Koroner. Yogyakarta: Istana Media, 2014.

[5] W. Wahyuni and I. Silvitasari, "Progressive Muscle Relaxation of Compelemtary Therapy and Sirma's Dyeing tea for Decreasing Blood Pressure on the Hypertension," IOSR J. Nurs. Heal. Sci., vol. 6, no. 1, pp. 46-49, 2017.

[6] I. Sulistyarini and U. I. Indonesia, "Terapi Relaksasi untuk Menurunkan Tekanan Darah dan Meningkatkan Kualitas Hidup Penderita Hipertensi," J. Psikol., vol. 40, no. 1, pp. 28-38, 2013.

[7] Wahyuni and F. E. Suryani, "Pengaruh Pemberian Terapi Jus Buah Tomat terhadap Penurunan Tekanan Darah pada Penderita Hipertensi Primer Stage 1 di Desa Monggot Kecamatan Geyer Kabupaten Grobogan," Urecol Univ. Muhammadiyah Magelang, pp. 245-250, 2017.

[8] R. Y. Aspiani, Buku Ajar Asuhan Keperawatan Gerontik. Jakarta: Trans Info Media, 2014.

[9] A. Mahatidanar and K. Nisa, "Pengaruh Musik Klasik Terhadap Penurunan Tekanan Darah pada Lansia Penderita Hipertensi Effect of Classical Music to Decrease of Blood Pressure in Elderly Patients with Hypertension," Agromed Unila, vol. 4, pp. 264-268, 2017.

[10] I. N. Wirakhmi, T. Utami, and I. Purnawan, "Comparison of Listening Mozart Music With Murotal Al Quran on the Pain of Hypertension Patients," J. Keperawatan Soedirman, vol. 13, no. 3, p. $100,2018$.

[11] Haryanto, "Jurnal Keperawatan dan Kesehatan, Vol. II No. 2, Mei 2014,” J. Keperawatan dan Kesehat., vol. II, no. 2, pp. 12-25, 2014

[12] N. Ghimire, R. Yadav, and S. Mukhopadhyay, "Comparative Study of Heart Rate, Blood Pressure and Selective Attention of Subjects Before and After Music," Birat J. Heal. Sci., vol. 4, no. 1, pp. 625-628, 2019. 